\title{
Development of an Alternative Enzyme-assisted Dehairing Method of Animal Skins using Proteases from Bacillus licheniformis MZK05M9
}

\author{
Md. Arafat Al Mamun', Md. Abir Hosain², Sobur Ahmed³, Fatema-Tuj-Zohra ${ }^{3}$, Rajia Sultana', Md. Murad Khan², \\ Marufa Zerin Akhter ${ }^{2}$, Shakila Nargis Khan² and Md. Mozammel Hoq²* \\ ${ }^{1}$ Centre for Advanced Research in Sciences (CARS), University of Dhaka, Dhaka-1000, ${ }^{2}$ Department of Microbiology, University of Dhaka, Dhaka- \\ 1000. ${ }^{3}$ Institute of Leather Engineering and Technology, University of Dhaka, Dhaka-1000, Bangladesh.
}

\begin{abstract}
The present study was aimed to develop an enzyme assisted dehairing method as an alternative and ecofriendly technique to reduce the use of harsh chemicals in leather manufacturing. For this purpose, two proteases namely alkaline protease $(601 \mathrm{U} / \mathrm{ml})$ and keratinase $(132 \mathrm{U} / \mathrm{ml})$ were produced by Bacillus licheniformis MZK05M9 (BIM9) in Soya molasses medium and Feather mill medium respectively, in $7.0 \mathrm{~L}$ bioreactor at $\mathrm{pH}$ 7.5 and $37^{\circ} \mathrm{C}$. The cell free enzyme preparations were used together at $2.5 \%$ level in dehairing experiments. Three sets of experiments for dehairing of goat skins were performed with (1) enzymes; (2) enzymes and 5\% lime (CaO) and (3) $2 \%$ sodium sulfide $\left(\mathrm{Na}_{2} \mathrm{~S}\right)$ and $5 \%$ lime. The treatment with enzymes removed $85 \%$ of hair from goat skin after 24 hrs under mild shaking condition at room temperature where as the treatment with enzymes and $5 \%$ lime together resulted in $\mathbf{1 0 0} \%$ dehairing under similar conditions. Sodium sulfide along with lime also removed $\mathbf{1 0 0 \%}$ hair faster (with $20 \mathrm{hrs)}$ than other two treatments. The grain surface of the enzyme treated skin was smoother and silkier than that of the chemicals treatment as revealed by Scanning Electron Microscopy. Thus these results indicated that, the enzyme assisted method can be applied in largescale dehairing trial to reduce the use of harsh sodium sulfide.
\end{abstract}

Keywords: Bacillus licheniformis MZK05M9 (BIM9), eco-friendly, enzyme assisted process, dehairing.

\section{Introduction}

Leather industries (Tanneries) offer various advantages in terms of manufacturing capacity and export potential ${ }^{1}$. There are about more than 200 tanneries in Bangladesh producing and exporting quality leathers with good international reputation and have been ranked fifth in the country's export earning sectors². About 25 hectares of land area has been occupied by the tannery industries at Hazaribagh, the south-west part of the capital city Dhaka. The tanning industries of Hazaribagh are processing approximately 220 metric tons of hide daily with an associated release of 600 $1000 \mathrm{Kg}$ of solid waste resulting from the production of each ton processed hide ${ }^{3}$. Animal skins/hides, byproduct of meat industries, are composed of proteins (90-95\% of solid, 35\% by weight), lipids, carbohydrates, mineral salts and water. Among several classes of proteins (collagen, elastin, keratin, glycoproteins, albumins and globulins), collagen is present in largest amount and is responsible for the formation of leather by combining with tanning agent ${ }^{4}$. The animal skins/hides have different processing steps like soaking, dehairing, deliming, bating, degreasing, pickling and tanning in beamhouse operations to prepare stabilized collagenous leather products ${ }^{5}$. For this purpose, all local tanneries still use traditional leather processing method utilizing toxic chemicals. The conventional chemical leather processing generates huge amount of environmental pollutions ${ }^{4,6}$. Dehairing process, based on the use of lime and sodium sulfide, excretes highly alkaline effluent which contributes to $50-60 \%$ of total aquatic pollution load in terms of biochemical oxygen demand (BOD), chemical oxygen demand (COD), total dissolved solids (TDS) and total suspended solids (TSS) ${ }^{7,8}$. The highly alkaline sodium sulfide having obnoxious odor is very toxic and can cause skin burn. Moreover, in oxidation-reduction reaction sodium sulfide produces hydrogen sulfide which is proven to be fatal even in concentrations as low as $200 \mathrm{ppm}^{9,10}$. Hydrogen sulfide also reacts with water and produces sulfuric acid that causes health hazards to the tannery workers and damage buildings, bridge etc. ${ }^{11}$. The extensive use of hazardous sulfide not only leads to unfavorable consequences on the health and environment but also undermines the efficiency of the effluent treatment plants ${ }^{12}$.

The above mentioned situations necessitate the use of an alternative and eco-friendly process, which is most likely could be accomplished by a process involving enzymes, to reduce environmental pollution ${ }^{13}$. So, the main objective of this research was to develop an enzymatic unhairing process for total substitution of the toxic sodium sulfide, and to reduce the environmental impact of leather production. Goat skins were treated several times by enzyme assisted and enzyme mediated method to develop a suitable ecofriendly dehairing process. 


\section{Materials and Methods}

\section{Bacterial strain}

Bacillus licheniformis MZK05M9 (BlM9), a mutant strain developed in our laboratory ${ }^{14}$, that produced proteases (both keratinase and alkaline protease) was used in the present study. The stock cultures of the strain were maintained as glycerol stocks $(15 \% \mathrm{v} / \mathrm{v})$ and stored at $-80^{\circ} \mathrm{C}$.

\section{Enzyme production}

Production of alkaline protease by Bacillus licheniformis MZK05M9 (BlM9) was carried out in Molasses soya meal medium containing (g/l): soybean meal 10 , molasses 5.0, $\mathrm{K}_{2} \mathrm{HPO}_{4}$ 3.0, $\mathrm{MgSO}_{4} \cdot 7 \mathrm{H}_{2} \mathrm{O} 0.5, \mathrm{NaCl} 0.5$ and $\mathrm{CaCl}_{2} \cdot 2 \mathrm{H}_{2} \mathrm{O}$ 0.5. Cultivations were performed in a 7 liter laboratory scale bioreactor (New Brunswick Scientific, USA) at $37^{\circ} \mathrm{C}$ and $\mathrm{pH} 7.5$ for $34 \mathrm{hrs}$. The dissolved oxygen concentration $\left(\mathrm{dO}_{2}\right)$ concentration was maintained at $30 \%$ by cascade control system. For keratinase production, BIM9 was cultivated in Feather meal broth (FMB) medium comprising of following constituents (g/l): $\mathrm{NH}_{4} \mathrm{Cl} 0.5$, $\mathrm{NaCl}$ 0.5, $\mathrm{KH}_{2} \mathrm{PO}_{4} 0.3, \mathrm{~K}_{2} \mathrm{HPO}_{4} 0.4, \mathrm{MgSO}_{4} 0.1$, feather meal 10 and yeast extract 0.1 in bioreactor in the same condition as applied for alkaline protease production. After separation of solid liquid by centrifugation, the supernatant was used as enzyme and applied for deharing of the goat skins.

\section{Enzyme assay}

\section{Proteolytic activity assay}

Proteolytic activity was determined with azocasein (Sigma Co. St. Louis. Mo.) as a substrate by a modified procedure described by Kreger and Lockwood (1981) ${ }^{15}$. In brief, 400 ìl of enzyme solution was incubated with 400 il of $1 \%$ azocasein solution in $0.05 \mathrm{M}$ Tris -HCI buffer at $\mathrm{pH} 8.5$ for 1 hour at $37^{\circ} \mathrm{C}$ in a water bath. The reaction was terminated by addition of $135 \mathrm{ml}$ of $35 \%$ trichloroacetic acid (TCA) and keeping the mixture at $4^{\circ} \mathrm{C}$ for 10 min. The reaction mixture was then centrifuged at $13,000 \mathrm{rpm}$ for $10 \mathrm{~min}$. Then $0.75 \mathrm{ml}$ supernatant was mixed with $0.75 \mathrm{ml}$ of $1.0 \mathrm{M}$ $\mathrm{NaOH}$ and the absorbance was read at $440 \mathrm{~nm}$ against the control. The control was treated in the same way, except TCA was added to the crude enzyme before mixing with azocasein solution. One unit of proteolytic activity was determined as the amount of enzyme that produces an increase in absorbance of 0.01 under the assay conditions.

\section{Keratinolytic activity assay}

The Keratinolytic activity of the enzyme preparations was determined using keratin powder ( TCI Co. Ltd. Tokyo) as substrate according to the method described by Hossain et al.(2007) ${ }^{16}$. In brief, $1 \mathrm{ml}$ of .05 M Tris- $\mathrm{HCl}, \mathrm{pH} 7.5$ containing 20 mg of keratin suspension was incubated with $250 \mu$ l of the enzyme solution for $30 \mathrm{~min}$ at $37^{\circ} \mathrm{C}$ with constant agitation at $120 \mathrm{rpm}$ in a water bath. The reaction was stopped by adding $500 \mu \mathrm{l}$ of $10 \%$ trichloroacetic acid (TCA) and then incubation at $4^{\circ} \mathrm{C}$ for $30 \mathrm{~min}$. Then reaction mixture was centrifuged at $10,000 \mathrm{~g}$ for $10 \mathrm{~min}$ and the supernatant was used to read the absorbance at $280 \mathrm{~nm}$ against a control. The control was treated in the same way, except that the TCA was added before the addition of enzyme solution. One unit of keratinolytic activity was determined as the amount of enzyme that produced an increase in absorbance of 0.01 under the assay conditions.

\section{Dehairing tests}

Freshly flayed goat skin was obtained from the local slaughter house and washed properly with water and detergent to eliminate blood, dirt and other unwanted particles. After removing the adipose tissue layer with a knife the skin was cut into pieces $(6 \mathrm{~cm}$ $\mathrm{x} 6 \mathrm{~cm}$ ) and weighted. These pieces were used for dehairing studies- conventional (control), enzyme mediated and enzyme assisted methods. The pieces of the goat skin placed into a conical flasks (1000 $\mathrm{ml})$ containing water $(120 \mathrm{ml})$ to dip the skin pieces. In conventional method, $\mathrm{Na}_{2} \mathrm{~S} 2 \%$ and $\mathrm{CaO} 5 \%$ (of the skin weight) and in enzyme mediated method keratinase $2.5 \%$ and alkaline protease solutions $2.5 \%$ (of the water volume) were used for dehairing of the goat skin. For enzyme assisted method the piece of goat skin was soaked in $5 \% \mathrm{CaO}$ (w/w of the skin) solution for $6 \mathrm{hrs}$ at $37^{\circ} \mathrm{C}$. After $\mathrm{CaO}$ treatment, the skin piece was washed several times by tape water until $\mathrm{pH}$ of the skin dropped near 7.5. Then the piece of the goat skin dipped in $120 \mathrm{ml}$ of water in a 1000 ml conical flask and 2.5\% keratinase along with $2.5 \%$ alkaline protease solutions were added. All the flasks were transferred into orbital shaker rotating at $120 \mathrm{rpm}$ for $26 \mathrm{hrs}$ at $37^{\circ} \mathrm{C}$.

The efficiency of the dehairing methods to remove the hair from skin was evaluated by determining the area of the dehaired portion and expressed as the percentage of the area of the treated skin. The smoothness of grain surface of dehaired skin was examined by Electron microscopy (JSM 6490LA, Jeol, Japan).

\section{Results}

\section{Enzymes}

The enzyme activity of alkaline protease, obtained from Bacillus licheniformis MZK05M9 (BIM9) mutant strain growing on Soya meal medium under the condition of $37^{\circ} \mathrm{C}$ temperature and $\mathrm{pH}$ 7.5, was found to be $601 \mathrm{U} / \mathrm{ml}$ against the substrate azocasein whereas enzyme activity of BlM9keratinase, growing on Feather meal medium under the similar conditions, was determined $132 \mathrm{U} /$ ml using keratin powder as assay substrate.

Optimization of conditions for dehairing of goat skin by BlM9 enzymes

Conventional dehairing process using $\mathrm{CaO}$ and $\mathrm{Na}_{2} \mathrm{~S}$ needed 20 hrs for complete dehairing of the goat skin. On the other hand, the enzyme mediated and enzyme assisted methods produced different percent of dehaired yield after different treatment durations. From the results, it was found that the highest $85 \%$ and $100 \%$ dehaired area were resulted using enzyme mediated and enzyme assisted methods respectively (Figure 1). 


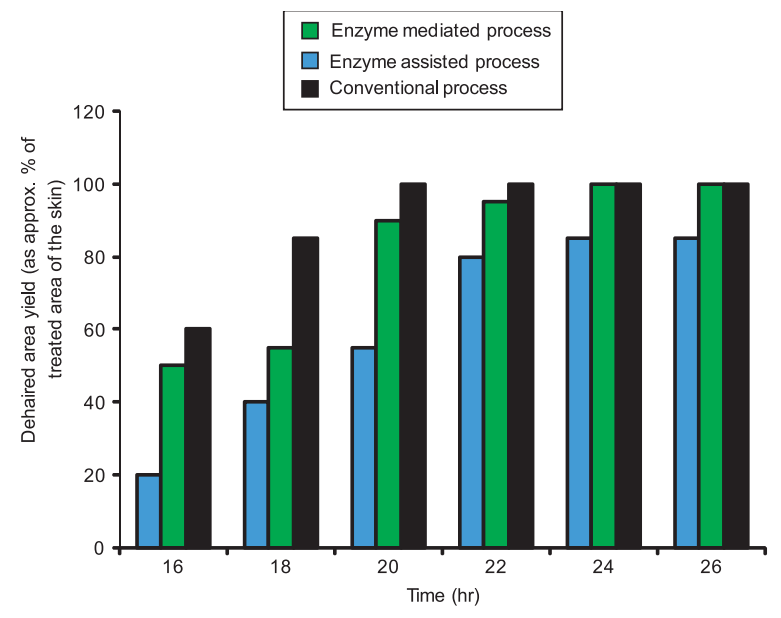

Figure 1. Comparative dehairing efficiency of enzyme assisted (enzyme +lime) and enzyme mediated (only enzyme) methods.

From the experiment it was revealed that the enzyme assisted method was comparable to conventional lime-sulfide method in complete deharing. Though the conventional lime-sulfide method required 20 hrs to dehair the goat skin completely as compared to $24 \mathrm{hrs}$ for the enzyme assisted method (Table 1), the surface of the skin dehaired by later method was smoother than that of the conventional method as observed visually (Figure 2).

Comparison between enzyme mediated and enzyme assisted method showed that complete dehairing was occurred by enzyme assisted method in small scale unhairing process. So, the only enzyme assisted method was applied to dehair a comparatively large $(40 \mathrm{~cm} \times 40 \mathrm{~cm})$ piece of goat skin. As expected, it also provided complete unhairing of the goatskin in large scale unhairing process (Figure 3 ).

Scanning electron microscopy (SEM) analysis of dehaired pelts SEM analysis of the grain surface of dehaired pieces of goat skin demonstrated that there was no apparent damage to the collagen fibre in both process but the grain surface appeared to be smoother in enzyme assisted process than conventional one (Figure 4).

Table 1. Effect of the BIM9 enzymes and chemical treatments on the dehaired area yield of the skin.

\begin{tabular}{|c|c|c|c|c|c|}
\hline $\begin{array}{l}\text { Type of } \\
\text { method }\end{array}$ & $\begin{array}{l}\text { Area of treated } \\
\text { skin }\left(\mathrm{cm}^{2}\right)\end{array}$ & $\begin{array}{l}\text { Dehairing } \\
\text { agents }\end{array}$ & $\begin{array}{l}\text { Duration of } \\
\text { treatment (hr) }\end{array}$ & $\begin{array}{c}\text { Dehaired skin area } \\
\text { obtained after } \\
\text { treatment }\left(\mathrm{cm}^{2}\right)\end{array}$ & $\begin{array}{l}\text { Area yield } \\
\text { (as \% of } \\
\text { treated area) }\end{array}$ \\
\hline Conventional & 36 & $2 \% \mathrm{Na}_{2} \mathrm{~S}$ and $5 \% \mathrm{CaO}$ & 20 & 36 & 100 \\
\hline Enzyme mediated & 36 & $\begin{array}{l}\text { 2.5\% keratinase + } \\
\text { 2.5\% alkaline protease }\end{array}$ & 26 & 30 & 85 \\
\hline Enzyme assisted & 36 & $\begin{array}{c}5 \% \mathrm{CaO}, 2.5 \% \text { keratinase and } \\
2.5 \% \text { alkaline protease }\end{array}$ & 24 & 36 & 100 \\
\hline
\end{tabular}
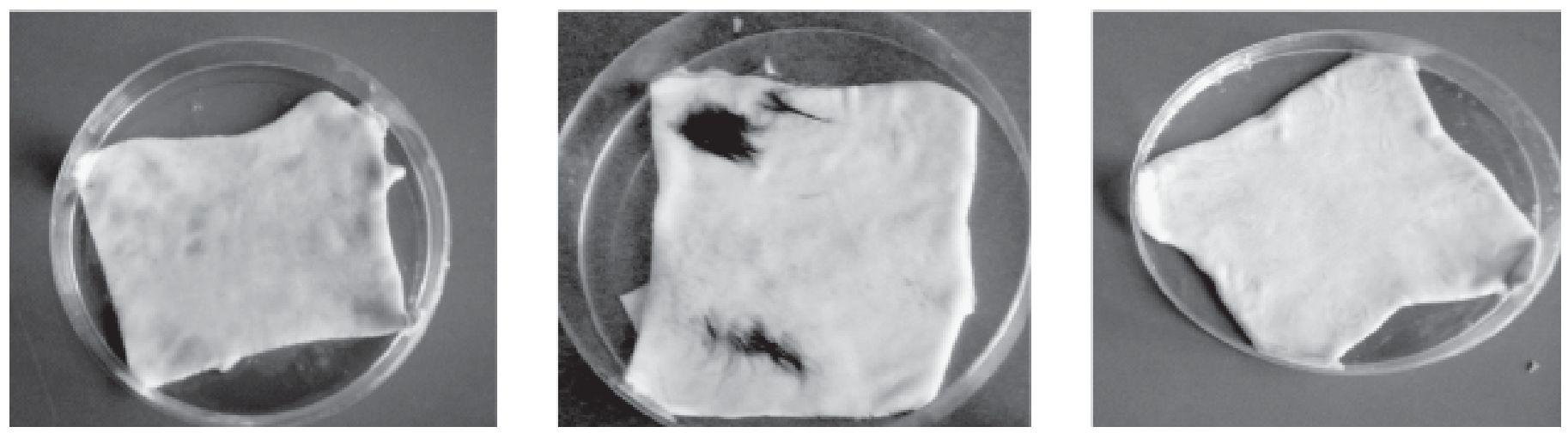

Figure 2. Evaluation of different treatment methods for dehairing of goat skins (small scale): (a) Conventional lime-sulfide method (b) Enzyme mediated method and (c) Enzyme assisted method. 


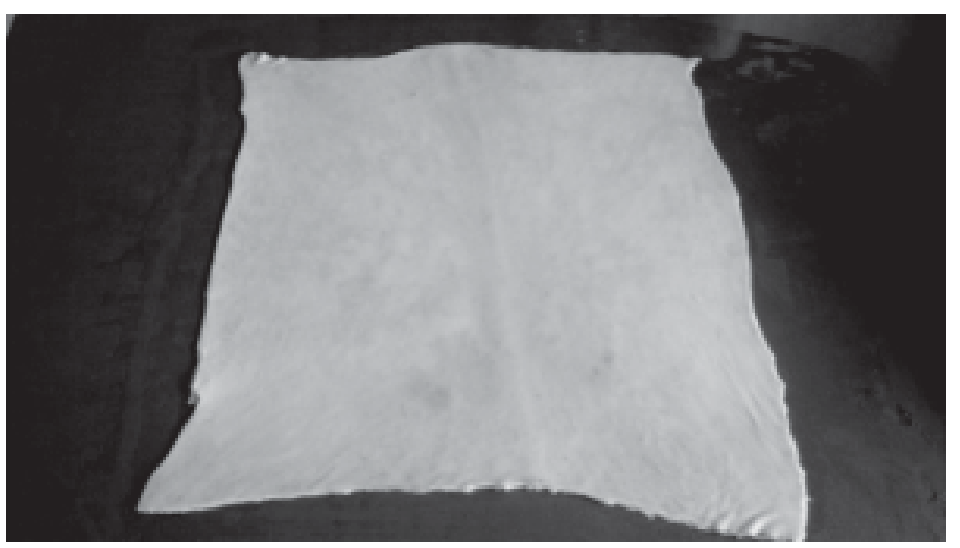

Figure 3. Efficiency of enzyme assisted method (5\% CaO and 2.5\% keratinase $+2.5 \%$ alkaline protease) for dehairing of large goat skin.
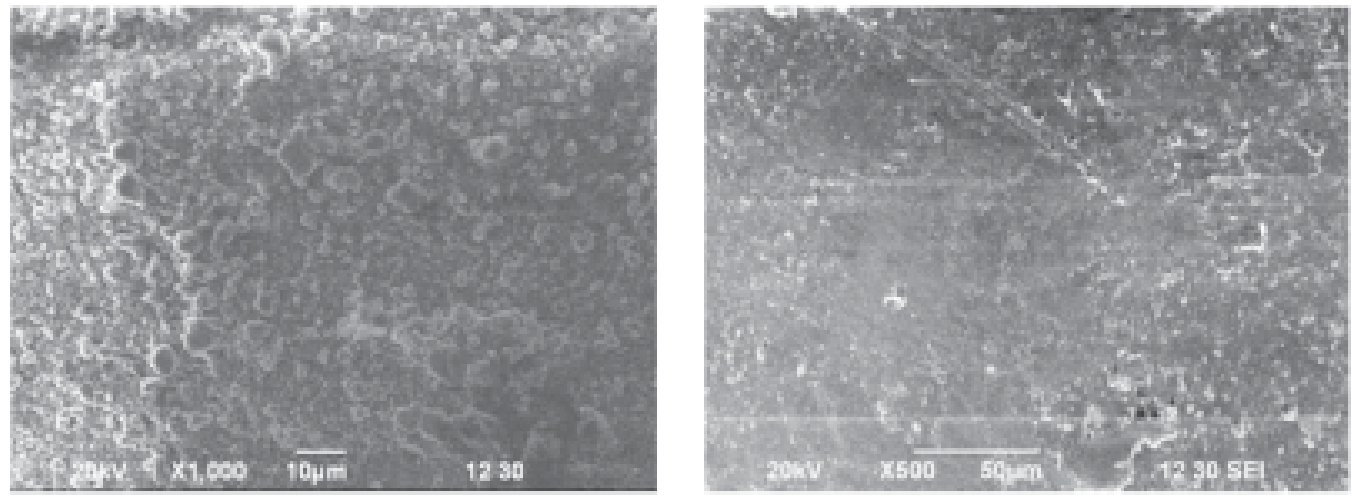

Figure 4. Scanning electron micrographs of the grain surface of goat skin dehaired by (a) Conventional lime-sulfide and (b) Enzyme assisted methods.

\section{Discussion}

Conventional dehairing of animal skins/hides in leather manufacturing, involves the generation of hydrogen sulfide with highly alkaline effluent due to the use of toxic chemicals like lime and sodium sulfide, can cause a serious health hazard to tannery workers and contributes to aquatic pollution. Thus the present work was performed to find out the possible eco-friendly dehairing process of animal skins using alkaline protease and keratinase preparation, obtained from a mutant Bacillus licheniformis MZK05M9 strain. Investigation of the dehaired skin upon treatment was carried to measure the area yield and as well as to determine visually the degree of its smoothness. The results exhibited that maximum area yield was found rapidly when skins were treated by conventional lime-sulfide method. However this treatment might have denatured and coagulated the skin proteins at high $\mathrm{pH}$ and subsequently the skin become wrinkled and lost its smoothness. On the other hand, skin treated by enzyme mediated (only enzyme treatment) method provided comparatively less area yield (85\%). But in case of enzyme assisted method i.e. treatment with $5 \% \mathrm{CaO}$ for 6 hrs followed by enzymatic action produced area yield comparable to the conventional method. This may be possible because of soaking the goat skin in $5 \%$
$\mathrm{CaO}$ solution, during which collagen fibers swelled osmotically by taking up water from the lime solution contributed by removing the electrical charge from the basic groups in collagen and changing the dimensions of its structure and this decreased the cohesive forces between the fibers by breaking $\mathrm{H}$-bonds, causing the fiber structure to become looser ${ }^{17,18}$ and opens up the collagen fiber bundles ${ }^{19}$. Thus protease enzymes can enter more easily into the skin and open the fibrous structure by degrading the inter fibrillar substances ${ }^{20}$. This is followed by loosening of hair with an attack by keratinase on the outmost sheath and subsequent swelling and breakdown of the inner root sheath $^{21}$.One of the advantage of the present enzyme assisted method is the short duration of soaking in lime solution does not damage the collagen fiber structure rather it helps accelerating the penetration of alkaline protease and keratinase through collagen matrix to act upon anchoring proteins around the hair follicles eventually facilitating the removal of hair. The Scanning Electron Microscopy study revealed that the surface of the skin treated with enzyme assisted method was smoother and silkier than that treated with lime sulfide method. Because lime-sulphide removes the hair above the epidermis for which the leather doesn't become silky, but the proteases attack the hair below the dermis and improve the silkier quality of the final leather preparations ${ }^{22}$. 


\section{Conclusions}

The developed enzyme assisted process resulted in reduction of the use of harsh chemicals associated with dehairing of animal skins and hides. As in Bangladesh leather industries still use conventional process for dehairing of skins, use of this enzyme assisted process can contribute to the reduction of environmental pollutions to the significant level and can be the good alternative, in terms of smoother grain surface and dehaired area yield, for the production of quality leather.

\section{References}

1. Luthra YK. 2006. Indian leather industry. Leather Age. March: 69-71.

2. Paul HL, Antunes APM, Covington AD, Evans P and Phillips PS. 2013. Bangladeshi Leather Industry: An overview of recent sustainable developments. J. Soc. Leath. Tech. Chem. 97: 25-32.

3. Hossain AMMM , Islam MS, Rahman MM, Mamun MM, Kazi MAI and Elahi SF. 2009. Assessment of tannery based chromium ecotoxicity through investigating regional bio-concentration in commercially produced chicken eggs and their physical properties. Bangladesh J. Sci. Ind. Res. 44(1): 11-30.

4. Kanagaraj J, Velappan KC, Chandra Babu NK and Sadullah S. 2006. Solid waste generation in the leather industry and its utilization for cleaner environment-a review. J. Sci. Ind. Res. 65: 541-548

5. Zambare VP, Nilegaonkar SS and Kanekar PP. 2013.Protease Production and Enzymatic Soaking of Salt-Preserved Buffalo Hides for Leather Processing. IIOAB Letters.3:1-7.

6. Thanikaivelan P, Rao JR, Nair BU and Ramasami T. 2004. Progress and recent trends in biotechnological methods for leather processing. Trends in Biotechnology. 22:181-188.

7. Marsal A, Cot J, Boza EG, Celma PJ and Manich AM. 1999. Oxidizing unhairing process with hair recovery. Part I. Experiments on the prior hair immunization. J. Soc. Leath. Tech. Chem. 83: 310-315.

8. Taylor MM, Bailey DG and Feairheller SH. 1987. A review of the uses of enzymes in tannery. J. Am. Leather Chem. As.82: 153-165.

9. Hannah RS and Roth SH. 1991. Chronic exposure to low concentrations of hydrogen sulfide produces abnormal growth in developing cerebellar Purkinje cells. Neurosci. Lett. 122: 225-228.
10. Roth SH, Skrajny B, and Reiffenstein RJ. 1995. Alteration of themorphology and neurochemistry of the developing mammalian nervous system by hydrogen sulphide. Clin. Exp. Pharmacol.22: 379-380.

11. Puvanakrishnan R and Dhar SC. 1988. Enzyme technology in beamhouse practice. Enzymes in Dehairing. NICLAI Publication, Chennai, India. 92-120.

12. Davies RM. 1997. Setting of consent limits for tanning industry trade effluents. J. Soc. Leather Tech. Chem. 81: 32-36.

13. Dettmer A, Gutterres M and Ayub MAZ. 2011. Hide unhairing and characterization of commercial enzymes used in leather manufacture. Braz. J. Chem. Eng. 28 (3): 373-380.

14. Salaheen S, Mamun MAA, Khan SN and Hoq MM. 2015. Improvement of Bacillus licheniformis MZK05 by mutation for increased production of keratinase. Dhaka Univ. J. Biol. Sci. 24(1): 17-23.

15. Kreger AS and Lockwood D. 1981. Detection of extracellular toxins produced by Vibrio vulnificus.Infect. Immun. 33: 583-90.

16. Hossain MS, Azad AK, Sayem A, Mostafa G and Hoq MM. 2007. Production and partial characterization of feather-degrading keratinolytic serine protease from Bacillus licheniformis MZK-3. J. Biol. Sci. 7 (4): 599-606.

17. Herfeld H and Schubert B. 1969. The influence of swelling and plumpness of animal hides in the liming process on the properties of leather. J. Am. Leather Chem.As. 64: 198-226.

18. Menderes O, Covington AD, Waite ER and Collins MJ. 2000. The mechanism and effects of collagen amide group hydrolysis during liming. J. Soc. Leath. Technol. Chem. 83:107-110.

19. Alexander KTW, Haines BM and Walker MP. 1986. Influence of proteoglycan removal on opening-up in the beamhouse. J. Am. Leather Chem. As.81: 85-102.

20. Sivasubramanian S, Manohar BM and Puvanakrishnan R. 2008. Ecofriendly lime and free enzymatic dehairing of skins and hides using a bacterial alkaline protease. Chemosphere.70: 1015-1024.

21. Alexander KTW. 1988. Enzymes in the tannery- catalysts for process. J.Am. Leather Chem. As. 83(9): 289-316.

22. Malathi S and Dhar SC. 1987. Production of extracellular protease by an Aspergillus flavus isolate and its application in the depilation of skin. Leather Sci. 34: 67-76. 